\title{
The financial sustainability challenges facing the South African non-profit sector
}

\begin{tabular}{|c|c|}
\hline \multicolumn{2}{|c|}{$\begin{array}{l}\text { Authors: } \\
\text { Mmabatho Maboya } \\
\text { Tracey McKay }{ }^{2}\end{array}$} \\
\hline \multicolumn{2}{|c|}{$\begin{array}{l}\text { Affiliations: } \\
{ }^{1} \text { Gordon Institute of Business } \\
\text { Science, University of Pretoria, } \\
\text { Pretoria, South Africa }\end{array}$} \\
\hline \multicolumn{2}{|c|}{$\begin{array}{l}{ }^{2} \text { Department of } \\
\text { Environmental Science, } \\
\text { University of South Africa, } \\
\text { Pretoria, South Africa }\end{array}$} \\
\hline \multicolumn{2}{|c|}{$\begin{array}{l}\text { Corresponding author: } \\
\text { Tracey McKay, } \\
\text { mckaytjm@unisa.ac.za }\end{array}$} \\
\hline \multicolumn{2}{|c|}{$\begin{array}{l}\text { Dates: } \\
\text { Received: } 04 \text { Apr. } 2019 \\
\text { Accepted: } 17 \text { Sept. } 2019 \\
\text { Published: } 19 \text { Nov. } 2019\end{array}$} \\
\hline \multicolumn{2}{|c|}{$\begin{array}{l}\text { How to cite this article: } \\
\text { Maboya, M. \& McKay, T., } \\
\text { 2019, 'The financial } \\
\text { sustainability challenges } \\
\text { facing the South African } \\
\text { non-profit sector', The } \\
\text { Journal for Transdisciplinary } \\
\text { Research in Southern Africa } \\
\text { 15(1), a693. https://doi.org/ } \\
\text { 10.4102/td.v15i1.693 }\end{array}$} \\
\hline \multicolumn{2}{|c|}{$\begin{array}{l}\text { Copyright: } \\
\text { (c) 2019. The Authors. } \\
\text { Licensee: AOSIS. This wc } \\
\text { is licensed under the } \\
\text { Creative Commons } \\
\text { Attribution License. }\end{array}$} \\
\hline \multicolumn{2}{|c|}{ Read online: } \\
\hline 口䘾回 & $\begin{array}{l}\text { Scan this QR } \\
\text { code with your } \\
\text { smart phone or } \\
\text { mobile device } \\
\text { to read online. }\end{array}$ \\
\hline
\end{tabular}

Non-profit organisations (NPOs) operating in South Africa are financially weak and the sustainability of their organisations is often at risk. Post-2008, large numbers have ceased to operate, in part, because of the weak state of the South African economy. This study sought to determine the financial conditions NPOs operate under, to establish why they are so vulnerable and present recommendations as to how they can become more financially resilient. In-depth interviews with 10 senior managers in the sector, representing organisations working in education, health and social welfare, were conducted. The results indicate that the legislative environment-governing NPOs are restrictive and may be inhibiting their ability to raise funds. The results of the interviews showed that the NPOs under study rely heavily on a few large donors; placing them at great risk, should they lose this revenue stream. Donor dependence is such that some even tailor their mandates to suit donors, whilst others dedicate a significant proportion of their resources to fundraising. Consequently, donor relations management and finding new or additional donors preoccupy the minds of NPO leadership. This is notably different to NPOs in the Global North where many have embraced social enterprise and commercialisation.

Keywords: financial sustainability; donor relations; non-profit organisations; funding challenges; policy.

\section{Introduction}

Non-profit organisations (NPOs) are often viewed as leaders in addressing challenging environmental and social issues plaguing society, especially in countries where state-led development is weak (Ilhan 2013; Reith 2010). This is particularly true for developing nations, where many international aid organisations support local NPOs, rather than for-profit organisations or even national governments, because NPOs have less bureaucratic processes, are more flexible in terms of entering into contracts and are less likely to be partisan (AbouAssi 2013; Hershey 2013; Ilhan 2013). Thus, NPOs in developing nations, often aid social transformation and assist in reducing inequality (Patel 2012; Salamon et al. 2013). Many also work in the environmental space (Liefferink \& Van Eeden 2010). In addition to the crucial social role that NPOs play in developing nations, the sector itself also has a significant economic footprint. It is a significant provider of employment opportunities and contributor to the gross domestic product (GDP) of many countries. For example, in the 15 countries that the Johns Hopkins Sector Report covered, NPOs contribute, on average, $4.5 \%$ of the GDP and account for $7.4 \%$ of the total workforce (Salamon et al. 2013). Nevertheless, although NPOs play a vital role when governments are either unable or incapable of solving chronic social issues, they cannot alone fulfil all of society's needs and must be supported by governments, as well as private sector donors (Hershey 2013; Lu 2015; Warshawsky 2016). They also face a number of significant challenges, the most important of which is securing funding. The aim of the study then was to understand the factors that affect and influence the financial sustainability of NPOs in South Africa. Thus, the research sought to explore the NPO revenue stream. As such it makes a contribution to the literature on the non-profit sector of the country, where academic studies are patchy (Claeyé \& Jackson 2012; Patel 2012; Swilling \& Russel 2002).

\section{The international perspective}

Despite the crucial role played by NPOs, they are not without criticism. Not all national governments are supportive of them, raising concerns about their motives. Some even argue that NPOs encourage citizen uprisings and regime change initiatives. Others claim that NPOs are engaging in illegal activities that compromise national sovereignty (Agence France-Presse 2014; Fraser 2005). Therefore, the ruling elite often contest the legitimacy of NPOs (Suleiman 2013). 
As a result, the non-profit funding landscape has evolved significantly since the 1980s (Hershey 2013). Initially, NPOs were viewed as a key conduit for developing and strengthening democracy and good governance in developing nations. To that end, funding, from international bodies, such as the World Bank and the European Union (EU), became significant (Habib 2005; Hershey 2013). Later, the donor funding landscape took a directional shift and began to focus more on poverty alleviation instead of broad empowerment (Banks \& Hulme 2012). In this regard, the World Bank and International Monetary Fund, for example, came to view NPOs as efficient, flexible and reliable, and thus elevated them to mainstream partners (Hershey 2013). In terms of developing nations, however, international financial support for local NPOs in the last decade has been scaled back. To a degree individual philanthropists, such as the Bill and Melinda Gates Foundation, have filled this gap but such philanthropists often bypass NPOs with significant ramifications for the NPOs in question (Fowler 2016). Furthermore, international donors now seldom fund local NPOs directly, rather channelling money via NPOs based in the Global North. In addition, Aschari-Lincoln and Jäger (2016) note that the funding landscape has changed with many funders demanding a high degree of financial transparency and adherence to good governance protocols. Potential funders often want access to the NPO's financial data and many demand rigorous reporting regimes, making funding applications overly complex and administrative, and thus, discriminating against small-scale NPOs located in developing nations. Consequently, such NPOs have suffered funding losses (Fowler 2016). Those who get funding find that they have to spend significant time, money and energy adhering to the bureaucratic reporting regimes required by donors. This renders them even more obliged to serve donor mandates (Banks \& Hulme 2012; Hershey 2013).

Another struggle for NPOs is that the sources of funding can also taint them in the eyes of local communities, who start to view them as agencies of the state or big business (Banks \& Hulme 2012). This is because, in part, of the imposition of specific (and often onerous) funding conditions on NPOs by some funders. Thus, over time, the activities of some NPOs become tailored to the demands of the donor. The NPO may even become financially dependent on donors - not only for money, but also for a raison d'être. As such, they may no longer effectively assist local communities (Reith 2010). Consequently, it has been argued by Reith (2010) and McKay, Mbanda and Lawton (2015) that in some cases, donors impose funding conditions that result in NPOs being forced to commit to the donor's agenda, regardless of what is needed or wanted at the local level. This dependence on donors weakens NPO legitimacy and opens NPOs up to criticism that they are merely self-serving (Suleiman 2013). Being dependent on donor funding renders NPOs especially vulnerable to donors' whims (AbouAssi 2013; De AndrésAlonso, Garcia-Rodriguez \& Romero-Merino 2015; Stecker 2014). For example, donors often revise their funding objectives independently of the NPOs they are working with, which can lead to a mismatch between the objectives of the donor and the NPO. This may result in the donor terminating the relationship, often with catastrophic financial consequences for the NPO (AbouAssi 2013). Additionally, if the prevailing economic environment negatively affects donors, sometimes funding is withdrawn (Aschari-Lincoln \& Jäger 2016; De Andrés-Alonso et al. 2015; Mayer et al. 2014; Stecker 2014; Unerman \& O'Dwyer 2010). Thus, Carroll and Stater (2009), Bowman (2011), AbouAssi $(2013,2015)$ and Chikoto and Neely (2014) all assert that high dependence on donor funding can make non-profits systemically vulnerable if the donor environment changes faster than the NPOs' capability to adjust to the changes. This is worsened by the fact that many struggle to achieve financial sustainability as they seldom are in a position to accumulate capital (AbouAssi 2013; Hershey 2013).

Thus, it is in the best interests of NPOs of the developing world to take financial sustainability, not just mission sustainability, into account when it comes to their planning and daily operations. This will include adopting a more business-like approach to survive. However, not all are willing, or able, to do this (Julie 2010). In particular, leadership matters: NPOs need boards of directors made up of people with the skills necessary to adopt a business-like approach (Hayman 2016). As Lehner (2013) notes, however, most NPOs are established, and led, by people who do not have formal business or entrepreneurship experience. Thus, NPOs struggle with finance in general, as their leaders focus almost entirely on social causes and often lack an entrepreneurial mindset (Morris, Webb \& Franklin 2011). This is in addition to many NPOs being unable to embark on strategic longterm financial planning as they are locked into donorcontrolled funding cycles (Lehner 2013). Furthermore, most NPOs operate under hand-to-mouth conditions, surviving from one funding cycle to the next. Most have not developed new cultures and capabilities to diversify their revenue streams.

For these reasons, Hailey and Salway (2016) argue that sustainable NPOs must be able to adapt to a changing external environment, adjusting and revising their missions, as well as mobilising resources to meet new challenges. This includes a shift towards being more self-financing and self-reliant (Gras \& Mendoza-Abarca 2014; Stecker 2014). Accordingly, NPOs need to develop financial resourcing models that focus on revenue diversification (Chikoto \& Neely 2014; Stecker 2014). This includes creating alternative revenue streams (Yang, Lee \& Chang 2011). As a result, some NPOs, especially in the Global North, have increased their commercial activities (Kerlin \& Pollak 2011). It can, therefore, be posited that NPOs need to move into a position of financial strength and independence if they are to fully embrace their particular mandates (AbouAssi 2015; Carroll \& Stater 2009; Stecker 2014). In the light of this, some NPOs have developed alternative revenue streams (Yang et al. 2011). That is, some NPOs have become more corporatised and are pursuing active fund raising (Haltofová \& Štěpánková 2014). 
Thus, Yang et al. (2011) note a rise in commercialisation strategies by non-profits. For example, in 2002, NPOs based in the USA had a funding model split of: $54 \%$ commercial activities, $36 \%$ government subsidies and $10 \%$ public donations. This reflects attempts to develop an imperviousness to donor funding whims. This strategy is in line with Mayer et al.'s (2014) argument that revenue diversification positively influences the revenue stability of NPOs. This may include adopting commercialisation strategies (Julie 2010; Yang et al. 2011). However, Grimes (2010) and Suleiman (2013) argue that this change may compromise the social mission of many NPOs; particularly when they take on a more entrepreneurial approach, as this can lead to the organisation drifting away from fulfilling their mandate and becoming self-serving. Gras and Mendoza-Abarca (2014) and Grasse, Whaley and Ihrke (2015) also warn that diversification could result in exposure to external risks which could negatively affect existing revenue sources, or crowd some of them out. Accordingly, self-financing cannot be the holy grail of financial sustainability (Yang et al. 2011). To that end, revenue diversification needs to be viewed as a strategy for managing pressure from external forces rather than an end in itself (Grasse et al. 2015; Hailey \& Salway 2016). The focus needs to be on diversification of income to minimise the impact of 'external financial shocks' and revenue volatility, as well as mitigate against the inherent social, political and economic risks of operating in the developing world (Aschari-Lincoln \& Jäger 2016; Chikoto \& Neely 2014). However, Grasse et al. (2015) maintain that a blanket approach towards diversification could lead to internal inefficiencies. Therefore, revenue diversification is but one element of successful revenue management (Bowman 2011).

Nonetheless, some NPOs simply cannot be self-financing because of their geographical location and the type of communities they serve (Aschari-Lincoln \& Jäger 2016). For example, NPOs in the developing world are far less able to adopt income-generating approaches, whilst those in the Global North are more able to attract donor funding, regardless of the level of need (Leonard 2014). That NPOs in developing nations are not able to diversify was highlighted by the 2008 global economic recession (Akintola et al. 2016). The impact of this recession was especially hard on these NPOs, with many having to radically restructure, ration services to beneficiaries, reduce staff numbers and costs. Some even closed down (Grasse et al. 2015). Unfortunately, these crisis-management type of coping strategies create a vicious circle, causing reputational damage and further weakening the sector; as an NPO needs goodwill, a sound reputation, a strong public profile to attract resources, as well as good relations with both donors and communities (Bowman 2011; De Andrés-Alonso et al. 2015; Grasse et al. 2015). Hence, building the internal capacity to learn and evolve is vital (Hailey \& Salway 2016).

\section{The non-profit funding landscape in South Africa}

In South Africa, NPOs have a chequered history (Patel 2012). In the 1980s and 1990s, international donor funds flooded into the country to support the anti-apartheid movement, and, as a result, the apartheid state regarded most of them with hostility. This money led to the expansion of the non-profit sector (Akintola et al. 2016; Leonard 2014; Habib 2005; Habib \& Taylor 1999). Swilling and Russell (2002) estimated that by the end of the 1990s, there were some 98920 NPOs. At the time, as the (apartheid) government provided subpar social services to the marginalised black majority (most of whom were - and are - poor), most NPOs aimed (in part) to reduce poverty and inequality amongst the black population (Habib 2005; Habib \& Taylor 1999). In the early post-apartheid years, official donor aid from international donors grew substantially, such that it accounted for between $2.2 \%$ and $2.5 \%$ of the South African national budget between 1994 and 1998. As a result, many South African NPOs, especially those who work in the fields of human rights and social justice sector, became entirely dependent on foreign donors (Ewing \& Guliwe 2008). Because of their role in the anti-apartheid movement, the post-apartheid state initially lauded NPOs as 'partners' of the new government (Habib 2005; Kajiita \& Kang'ethe 2017; Van Pletzen et al. 2014). Evidence can be seen in the various pieces of legislation passed, such as the National Water Act (Act No 36 of 1998) and the National Environmental Management Act (Act No 107 of 1998) which both call for local communities and civil society to be involved in decision-making. Additionally, the National Development Plan of 2030 calls for an 'Active citizenry and social activism ... to raise the concerns of the voiceless and marginalised' (South African Government n.d.).

At the same time, the government promulgated legislation to channel international donor funds to various state causes, such as the Reconstruction and Development Programme (RDP). In 1996, ostensibly as part of this 'partnership', the newly elected South African State established the Transitional National Development Trust (Habib \& Taylor 1999). In this regard, the South African government pressurised international donors, through bilateral agreements, to shift towards funding government-to-government programmes (Julie 2010). Controlling the flow of funds to NPOs was subsequently formalised with the promulgation of the NonProfit Organisations Act No. 71 of 1997 (Husy \& Taback 2005; Van Pletzen et al. 2014). This act imposed much more state control over NPOs, such as mandating that they must be organisations established for the public benefit and 'the income and property are not distributable to its members or office bearers except as reasonable compensation for services rendered'. Additionally, regulations in the South African Income Tax Act (No 58 of 1962) Section 30 (which pertains to public benefit organisations such as NPOs) give NPOs the right to generate a taxable income, but state that profits must be reinvested to further their mission (Department of Social Development 2009). The same act also requires approved public benefit organisations to have at least three persons, who are not connected persons (as defined) in relation to each other to accept fiduciary responsibility for the company. ${ }^{1}$

1.To comply with the law, some lawyers advise NPOs that they should: (1) ensure directors meet four times a year, (2) agendas circulated 2 weeks in advance, directors meet four times a year, (2) agendas circulated 2 weeks in advance, (3) board meetings must cover operations and governance aspects and (4) draft minutes containing action items should be produced within 7 days after the board meeting took place. These conditions are onerous for many NPOs because of financial and human resource capacity constraints. Some who do not consult lawyers may even be unaware of their legal obligations. 
Non-profit organisations also have to register themselves on a national database and submit annual audited financial reports to the state in order to continue to operate. By 2014, some 127032 NPOs were officially registered, up from 85478 in 2012. The majority (120 268 or $95 \%$ ) of these registered NPOs are voluntary associations such as community-based organisations and professional associations, mostly small in size and finances (Statistics South Africa [StatsSA] 2012). Notwithstanding the importance ascribed to civil society, and the extent to which the state controls them, the South African government's financial support of NPOs is poor (Patel 2012). As a result, most NPOs in South Africa receive income from three sources, namely: government grants, donations and membership subscriptions. However, the reliance on government grants and corporate sponsorship has led many to adopt the burdensome King IV Corporate Governance code (Cliffe Dekker Hofmeyr 2019), despite this code being, for the most part, inappropriate for NPOs. This may also be linked to the imposition of managerialism on the sector, as noted by Claeyé and Jackson (2012).

Post-2008 has been a significantly trying time for these organisations because of the effects of the global recession and South Africa's shrinking economy. Donor funding and development aid declined sharply and have remained low (Akintola et al. 2016; Leonard 2014; Van Pletzen et al. 2014). Additionally, many are struggling to get grants from the state-controlled national lottery (known as LOTTO). ${ }^{2}$ More recently, there have also been accusations of corruption in the LOTTO payments. ${ }^{3}$ This has serious ramifications for the NPOs, which, for the most part, cannot compete with the national lottery, which required permits issued by the state (National Lotteries Commission, 2019). Consequently, many NPOs ceased to exist, with some 30000 deregistered by 2018 (SANGONet, 2018). Others have had to restructure, ration services and reduce staff (Akintola et al. 2016). The consequences were also felt nationally with reduced social services, education and health services as some NPOs do not offer their services anymore, or have scaled back (StatsSA 2012). The loss of jobs is also a problem, as most NPOs spend around $74 \%$ of their income on salaries, so job losses mean less money circulating in the local economy. Those NPOs that had survived had to form networks and coalitions to support one another. It became clear that sustainability required organisational attributes such as credibility, recognition as legitimate in the regulatory and political space, as well as an ability to mobilise resources (Hayman 2016). A few did launch income-generating programmes, and some realised that the concept of NPOs as purely non-profit had to change (Julie 2010).

\section{Methodology}

Because of time and financial constraints, non-probability, convenience sampling was used to select 10 NPOs. The possibilities of having a near-homogeneous sample and its 2.Non-profit organisations demand audit of lottery payments (News24, 2012).

3.Lottery grants under investigation (Lowvelder, 2018) limitations were considered; hence, the diversity of selected NPOs (albeit in a smaller sample size) was important in qualifying the unlikeliness of a homogeneous approach to financial sustainability in a diversified sample. Senior managers from metropolitan South African NPOs (operating in a range of areas such as education, environment and social justice), established for more than 5 years, were interviewed (see Table 1). The average age of the NPOs that formed part of the study was 32 years. The selected NPOs varied in terms of organisational sizes (large, small, national and international). The total value of the 10 NPOs in terms of turnover was R366 million with 458 employees in total (ranging from four to 145 employees per NPO).

The research followed an inductive exploratory approach using qualitative in-depth interviews with an interpretivist approach (see Appendix 1) (Saunders \& Lewis 2012). The nature of the interviews was based on experienced survey principles that work well in interviews that do not require a representative probability sample (Zikmund et al. 2013). The interviews were preceded by a short discussion on the background of the organisation and its most important milestones; this was to enable the interviewees to participate freely in the interviews. Ethical clearance was granted from the Gordon Institute of Business Studies. The participants gave informed consent; the interviews were recorded and then transcribed for analysis in Atlas.ti. After cleaning and validation, coding resulted in 53 primary codes. The codes were organised into code families. These themes were then aggregated into categories of best fit, and standard deviation was used to rank them in order of importance. The data fell into four categories: extremely important, very important, important and less important.

\section{Findings}

It was possible to discern five key themes in order of importance: (1) donor relations, (2) identifying funding, (3) financial sustainability, (4) managing finances and (5) the role of the board. Each of these factors are presented in Table 2. These key themes will now be discussed.

\section{Donor relations}

Most participants indicated that as funding came from donors, they had to maintain good donor relations at all costs. P1 mentioned that over $90 \%$ of their funding comes from foreign donations and P2 qualified their position by saying: 'As a NPO we never going to be free of having to do fund raising'. Thus, the relationship with donors emerged as extremely important. P2 elucidated that funding depended on their relationship with donors, and that trends in the donor environment influenced their financial sustainability. P3 felt that their relationship with donors was unequal, because of their financial dependence on donors, making them obliged to address every donor demand: 'Important to understand their needs and ... satisfy their needs'. P7 also noted that despite spending a great amount of energy and 
TABLE 1: Profile of participants.

\begin{tabular}{lllll}
\hline Participant's position & Organisation's mission & Year established & Annual budget (million) & Main source of funding \\
\hline Senior manager & Social justice & 2006 & R 40 & International Donors \\
Chief Executive Officer & Social welfare & 1936 & R 23 & Government Grants \\
Executive director & Education & 2004 & R 80 & Corporate Donors \\
Finance manager & Social welfare & 2006 & R 35 & 145 \\
Chief Executive Officer & Social welfare & 1910 & R 44 & International Donors \\
Grants manager & Social justice & 2010 & R 27 & Government Grants \\
Chief Executive Officer & Social welfare & 2006 & R 1 & International Donors \\
Chief Executive Officer & Social justice & 1979 & R 12 & 32 \\
Chief operating Officer & Education & 1985 & R 100 & Individual donations \\
Chief Executive Officer & Youth development & 2009 & R 4 & Corporate Donors \\
\hline
\end{tabular}

TABLE 2: Key themes and their order of importance.

\begin{tabular}{|c|c|c|c|}
\hline Rank & Factors & $\begin{array}{l}\text { Total } \\
\text { mentions }\end{array}$ & $\begin{array}{l}\text { Category of } \\
\text { importance }\end{array}$ \\
\hline 1 & $\begin{array}{l}\text { Donor relations management, donor trends and } \\
\text { behaviour, accountability to donors, loss of donors }\end{array}$ & 298 & $\begin{array}{l}\text { Extremely } \\
\text { important }\end{array}$ \\
\hline 2 & $\begin{array}{l}\text { Identifying new funding for programmes, } \\
\text { delegating responsibility for this, following } \\
\text { fund raising leads, finding new donors }\end{array}$ & 248 & Very important \\
\hline 3 & $\begin{array}{l}\text { Having the skills and capacity to be financially } \\
\text { sustainable, planning and discussing financial } \\
\text { sustainability }\end{array}$ & 174 & Important \\
\hline 4 & $\begin{array}{l}\text { Analysis, review of financial position and } \\
\text { managing finance and investments, financial } \\
\text { reporting }\end{array}$ & 119 & Important \\
\hline 5 & $\begin{array}{l}\text { Role of the board, board governance and } \\
\text { oversight }\end{array}$ & 115 & Important \\
\hline 6 & Successful or good mission implementation & 77 & Less important \\
\hline 7 & Strategy development planning and monitoring & 53 & Less important \\
\hline 8 & Management oversight & 51 & Less important \\
\hline 9 & Pursuing alternative funding options & 35 & Less important \\
\hline 10 & The overall economic environment in South Africa & 29 & Less important \\
\hline 11 & Changing the NPO business model & 27 & Less important \\
\hline 11 & Collaborating with other organisations & 27 & Less important \\
\hline 12 & Reputation management & 18 & Less important \\
\hline 13 & Scaling down of programmes and reasons for & 10 & Less important \\
\hline 14 & $\begin{array}{l}\text { South African policy changes and political } \\
\text { uncertainty }\end{array}$ & 8 & Less important \\
\hline
\end{tabular}

NPO, non-profit organisation.

resources trying to keep their international donor, the donor still elected to start their own NPO. P2 also mentioned that:

... you really have to nurture your big donors ... when their strategy changes you need to talk to them and say is there any way we can adapt what we do to meet it.

Keeping donors happy and on board is then a top priority. Although donor demands can easily overwhelm the administrative capacity of NPOs, they are 'locked in' to the relationship, needing to remain on good terms with their donors to survive, despite the strategic risk of relying too heavily on donors (P7). In addition, some of the participants indicated that sometimes their current donors referred them to other potential donors. P1 mentioned that 'Other donors would serve as pointers ... Donors would say that there is this new donor ... so it would be nice for you to send in a proposal'. This is notwithstanding an environment where NPOs compete for donor funding.

\section{Sourcing new funding}

As donors are so vital, finding new donor funding was very important. In this regard, participants were concerned about: (1) how to fund programmes and (2) how to identify new funding avenues and new donors. P8 substantiated that:

As an NPO we have been financially dependent on donors a lot. Our skills are focused on writing proposals and sending proposals to donors, but with South Africa having been declared middle income country, and the current economic climate, it has become difficult to find funding.

P1, P6 and P10 all indicated that the identification of new donors was critical. In particular, because many NPOs faced challenges covering their overheads and other administrative costs. That is, donors are often reluctant to allocate funds for administration costs. Thus, most organisations were in permanent pursuit of new donors to make up shortfalls between income and expenses. Importantly, the dominance of donor relations and sourcing new funding indicates that these NPOs follow traditional NPO business models. Most have not attempted to generate alternative income sources; although some changed their business models to match donor behaviour and trends. For instance, P2 mentioned that on average donors 'last between 3 and 5 years and then they move on, and their funding criteria changes'.

There were also three themes ranked as important: (1) the human resources associated with planning and discussing financial sustainability, (2) analysis, review of financial position and managing finance and investments' financial reporting and (3) the role of the board, board governance and oversight. These three are presented below.

\section{Human resources associated with financial sustainability}

Financial sustainability refers to an organisation's ability to be in a positive financial position and has the financial means to implement their programmes. However, the results relating to financial sustainability were complex, showing that some senior employees do not grasp how their organisation can achieve long-term financial independence. Part of this was because of a weak understanding of what financial sustainability is. For example, when asked to explain their understanding of financial sustainability, P2 said, 'Well, in the perfect world we would have a big enough reserve to just live off the interest'. Thus, this manager 
wanted their NPO to be a type of 'trust-fund baby'. Even worse was the response from P5, who said:

A good NPO spends [all] the money it gets each year, so we don't store up huge amounts of reserves. The money goes the money's given to us to spend on the work. Financial sustainability is but one element, one element.

Thus, the value of having reserve funds for 'rainy days' was not a priority for this manager. P2, P4, P8 and P9 connected financial sustainability with their ability to fund their programmes, rather than as a specific goal to be achieved.

In clear contrast, P7 and P8 both rated an understanding of financial position as more important than strategy development and monitoring. Thus, some did understand financial sustainability. For example:

Financial sustainability is the ability to carry on as an organisation in a credible manner where you able to deliver programs and keep your promises to donors. Whilst keeping the lights on and keeping the staff employed. So it's basically the ability to continue.

Some of the participants highlighted the importance of adequate financial skills, as well as the continuous analysis and review of their organisation's financial positions as important elements of financial sustainability. P9 strongly highlighted the weak financial environment of South Africa as an ultimate threat to survival 'What is happening in the economy is a concern'. This was different to most participants who disregarded the impact of the country's policy changes and economic uncertainty on their financial sustainability.

\section{Financial position}

The majority, participants 1, 2, 3, 4 and 7, did not attach a high value to the management of finances and investments. Only a minority, participants 8 and 9 , rated an understanding of finance as more important than strategy development and monitoring. Key personnel - in terms of managing finances - were limited to the financial manager (who does the financial reporting), the board committee for finance and the Chief Executive Officer (CEO). Heavy reliance on the $\mathrm{CEO}$ to drive funding initiatives was particularly common. Thus, few NPO employees focused on this aspect of the organisation. Participant 7 did, however, recognise that the financial position of the NPO was important for general sustainability.

\section{Role of the board}

Whilst all the participants highlighted oversight by their board of directors as an important element of their financial affairs, some ranked accountability to their donors as more important. This is an indication of a resource dependency relationship. Notably, those NPOs debating or implementing alternative revenue streams placed greater emphasis on board oversight than the rest (P5 and P10). In this regard, participants 3, 7 and 9 noted that boards seldomly had directors who could provide insight into broader financial sustainability, or who knew how to pursue alternative funding sources. This speaks to a need to seek out board members with these kinds of skills. For example, participant 3 specifically mentioned this skills gap, and went on to note that when new board members were appointed, this particular NPO tried to select those who had the critical skills such as entrepreneurialism.

Lastly, there were themes that emerged as less important to the NPOs (see Table 2). Importantly, from the perspective of these NPOs, the following themes, which are actually key to long-term financial sustainabillity, were viewed as less important: (1) pursuing alternative funding options (35 mentions or $2.7 \%$ of all mentions) and (2) changing the NPO business model (27 mentions or $2 \%$ of all mentions). Most therefore are not paying attention to these critical issues.

\section{Discussion}

Overall, two chief concerns preoccupy the minds of the leadership of the NPOs under study. These are (1) donor relations management and (2) finding new or additional donors to fund their programmes. Of lessor importance are fundraising, having the skills and capacity to adequately manage their finances (oversight, reporting to donors), managing finances and board oversight. Thus, contrary to what Kerlin and Pollak (2011) indicate, there seems to be little effort by South African NPOs to increase their commercial activities as another income stream. This is validated by what the participants felt were less important. Thus, responses to the changing funding landscape were more in line with what Child (2010) described as an increased dependence on donor funding, making them even more vulnerable to financial 'shocks' and likely to lose their autonomy (Chikoto \& Neely 2014; Hillman 2009).

It can be concluded that most of the NPOs under study are dependent on donor finance, making their relations with donors of paramount importance. As a result, most go to great lengths to appease and humour their respective donors and implementing partners. Consequently, they felt that reputation management was crucial. In this regard, participants were keen to stress that their important need was to maintain an impeccable reputation. They felt that organisations with doubtful or tarnished reputations, or poor financial reporting, lost donors. To that end, following good governance principles and reporting standards, regardless of how onerous, were viewed as crucial to maintaining good donor relations. For those who had international donors and funders, who require arduous reporting processes, this was even more crucial. Thus, the NPOs divert time, energy and expertise away from delivering on their mandates to managing donor relations.

Their dependence on donors meant that in some cases, NPOs even implemented programmes at the behest of donors, thus losing the ability to 'steer their own ship', becoming an implementing agent of the donor instead. In line with other findings, their strategies for engaging with their donors are 
directed by resource dependency, taking the form of a master-servant relationship (Carroll \& Stater 2009; Froelich 1999; Grasse et al. 2015; Reith 2010). Trapped in this resource dependency paradigm, some posited that a solution was to have multiple donors rather than just one donor or secure long-term donors. This was despite some experiencing 'neardeath' situations, when large donors suddenly withdrew their funding and the NPO faced the real possibility of closing down. Notwithstanding being fully aware of the challenges and risks involved in over-dependence on donors, most could not think beyond the old 'tried and trusted' ways of sustaining their NPOs. This attitude aligns to that of many NPOs in the developing world (Hailey \& Salway 2016).

In part, this was because of a limited understanding of what long-term financial sustainability is, not recognising the importance of having their own resource base to sustain their operations. Most of the participants also did not realise that to develop alternative funding sources, the NPO itself would have to invest money into the alternative. Thus, rather simplistically, they planned to ask their current donors for the necessary financial support for this! In stark contrast to this, one NPO indicated that their organisation borrowed money to participate in Black Economic Empowerment deals. This strategy paid off, as returns were used to repay the loans and develop enough capital to make the NPO independent of donor funding. To limit the risks associated with this, the NPO had to establish a separate investment company (with the NPO board providing oversight). This approach, however, is only possible if an organisation has assets that can be used as collateral for raising investment finance.

Very few were keen on developing self-generated income sources and even the ones who have explored the idea had not implemented it. Therefore, although some recognised the importance of alternative revenue streams, most had not adopted practical strategies to pursue alternative approaches. Some participants did not even prioritise being autonomous from donors, with no appetite for finding alternative sources of funding at all. Some were worried that having self-generated sources of funding would jeopardise their status as NPOs, that their image would be negatively affected or that it would have tax implications. In this regard, it is clear that many do not understand the various pieces of legislation that govern the sector. Others felt that challenges would arise regarding the management and expertise required to have self-generated sources of funding. The participants did, however, identify a possible range of revenue streams such as creating products for enterprises, endowment funds and cash reserves (of between 3 months and 3 years). One had set money aside and was currently looking for investment strategists to help them invest the money. Another one said their organisation made finding alternative revenue sources paramount.

\section{Recommendations}

In terms of long-term financial sustainability, it is imperative for South African NPOs to achieve a healthy balance between donor funding and independent financial resources. This would enable them to overcome donor pressures and retain autonomy with regard to their mandates (Hershey 2013). It would also make them more resilient to changes in the donor and economic landscape. Thus, NPOs could consider strategies such as investing in income-generating programmes, with the recruitment of collaborative partners or financial strategists to assist them in this endeavour. Furthermore, multiyear and long-term donor funding may afford the organisations with an opportunity to plan for financial sustainability without the pressures of short-term fundraising targets. In addition, the NPOs should ensure that they pull together these strategies by raising the importance of strategic stakeholder relations within their organisation. This overarching strategy can provide the organisational assurance for managing the programme implementation and funding uncertainties (Bowman 2011; Grasse et al. 2015).

It may, however, also be necessary to get donor permission to use some of the donor's funds to invest in establishing income generation projects to assist the NPOs to achieve some modicum of financial independence in the long term. Non-profit organisations can also consciously increase the utility of the goods and services they provide to their beneficiaries by positioning them into their income generation projects. For example, providing low-cost family counselling for those who can pay, then using the funds generated from this to cross-subsidise those who cannot pay. However, this would necessitate an entrepreneurial mindset and recognition of the income-generating potential of their existing programmes. More importantly, increasing their risk appetite, embracing the inherent investment risks associated with income-generating projects and a willingness to invest some of their reserves towards income generation is crucial. Finally, there may also be a need to address the misunderstandings that seem to prevail about the legislative prescriptions on NPOs in South Africa, as many NPOs seem to think that they are not allowed to carry money over from one financial year to the next, retain income or even have investments.

\section{Conclusion}

The South African NPOs that formed part of this study focus primarily on developing and maintaining their donor base, and thus, to a large degree have not - and nor do they intend to - adopted alternative revenue streams or become more corporatised. Therefore, the securing of long-term donors emerged as the most important issue for these NPOs, rather than trying to gain some independence from donors. They are overly reliant on a few large donors and this causes them to invest heavily (in terms of time, money and effort) in donor and stakeholder relations. This may compromise their ability to perform their mandates and hinder their autonomy. Seemingly, large donors wield significant influence on the NPOs. These NPOs are vulnerable to changes in donor profiles, priorities or to losing donors altogether. The development of a more diverse financial strategy would 
enable them to handle financial uncertainties better. To that end, appointments at board level need to take into account the suite of skills needed to assist NPOs in this regard.

\section{Acknowledgements}

The authors would like to thank the NPOs which participated, as well as Milton Milaras, Brij Maharaj and Richard Ballard for their insightful comments.

\section{Competing interests}

The authors declare that they have no financial or personal relationships that may have inappropriately influenced them in writing this article.

\section{Authors' contributions}

M.M. was deeply involved in the conception and design of the study, the acquisition of data, the analysis and interpretation thereof, as well as the write-up. The article flows from her MBA. T.M. guided the conception and design of the study, informed and contributed to the data analysis and interpretation, as well as assisted with the crafting and editing of the article for submission. Tracey was the supervisor of the MBA from which the article flows.

\section{Ethical consideration}

Ethics clearance was received from Gordon Institute of Business Science (GIBS), University of Pretoria (Ethical Clearance number: Temp2016-01798).

\section{Funding information}

This research received no specific grant from any funding agency in the public, commercial or not-for-profit sectors.

\section{Data availability statement}

Data sharing is not applicable to this article as no new data were created or analysed in this study.

\section{Disclaimer}

The views and opinions expressed in this article are those of the authors and do not necessarily reflect the official policy or position of any affiliated agency of the authors.

\section{References}

AbouAssi, K., 2013, 'Hands in the pockets of mercurial donors: NPO response to shifting funding priorities', Nonprofit and Voluntary Sector Quarterly 42(3), 584-602. https://doi.org/10.1177/0899764012439629

AbouAssi, K., 2015, 'Testing resource dependency as a motivator for NPO selfregulation: Suggestive evidence from the developing nations', Nonprofit and
Voluntary Sector Quarterly 44(6), 1255-1273. https://doi.org/10.1177/08997 Voluntary Sector
64014556774

Agence France-Presse (AFP), 2014, Kenya closes down hundreds of NPOs, viewed 15 March 2018, from https://www.aljazeera.com/news/africa/2014/12/kenyacloses-down-hundreds-NPOs-20141216124722577348.html.
cloms

Akintola, O., Gwelo, N.B., Labonté, R. \& Appadu, T., 2016, 'The global financial crisis: Experiences of and implications for community-based organizations providing health and social services in South Africa', Critical Public Health 26(3), 307-321. https://doi.org/10.1080/09581596.2015.1085959
Aschari-Lincoln, J. \& Jager, U.P., 2016, 'Analysis of determinants of revenue sources for international NPOs: Influence of beneficiaries and organizational characteristics', Nonprofit and Voluntary Sector Quarterly 45(3), 612-629. https://doi.org/10.1177/ 0899764015595721

Banks, N. \& Hulme, D., 2012, The role of NPOs and civil society in development and poverty reduction, BWPI Working Paper 171, viewed 11 October 2019, from https://doi.org/10.2139/ssrn.2072157

Bowman, W., 2011, 'Financial capacity and sustainability of ordinary nonprofits', Nonprofit Management and Leadership 22(1), 37-51. https://doi.org/10.1002/ $\mathrm{nml} .20039$

Carroll, D.A. \& Stater, K.J., 2009, 'Revenue diversification in nonprofit organizations: Does it lead to financial stability?', Journal of Public Administration Research and Theory 19(4), 947-966. https://doi.org/10.1093/jopart/mun025

Chikoto, G.L. \& Neely, D.G., 2014, 'Building nonprofit financial capacity: The impact of revenue concentration and overhead costs', Nonprofit and Voluntary Sector Quarterly 43(3), 570-588. https://doi.org/10.1177/0899764012474120

Child, C., 2010, 'Whither the turn? The ambiguous nature of nonprofits' commercial revenue', Social Forces 89(1), 145-161. https://doi.org/10.1353/sof.2010.0058

Claeyé, F. \& Jackson, T., 2012, 'The iron cage re-revisited: Institutional isomorphism in non-profit organisations in South Africa', Journal of International Development 24(5), 602-622. https://doi.org/10.1002/jid.2852

Cliffe Dekker Hofmeyr, 2019, King IV an overview, viewed n.d., from https://www. cliffedekkerhofmeyr.com/export/sites/cdh/en/practice-areas/downloads/KingIV-Information-Brochure.pdf.

De Andrés-Alonso, P., Garcia-Rodriguez, I. \& Romero-Merino, M.E., 2015, 'The dangers of assessing the financial vulnerability of nonprofits using traditional measures', Nonprofit Management and Leadership 25(4), 371-382. https://doi.org/10.1002/ nonprofit 21134

Department of Social Development, 2009, Developing good governance practices within the South African NPO Sector, Department of Social Development. Pretoria, viewed 11 October 2019, from http://www.dsd.gov.za/npo/index.php?option= viewed 11 October 2019, from http://www.dsd.gov.za/n
com_docman\&task=doc_download\&gid=66\&Itemid=116.

Ewing, D. \& Guliwe, T., 2008, 'Foreign donor funding since 1994', in A. Habib \& B. Maharaj (eds.), Giving \& solidarity, pp. 241-280, HSRC Press, Cape Town.

Fowler, A., 2016, 'Non-governmental development organisations' sustainability, partnership, and resourcing: Futuristic reflections on a problematic trialogue', Development in Practice 26(5), 569-579. https://doi.org/10.1080/09614524.201 6.1188883

Fraser, A., 2005, 'Poverty reduction strategy papers: Now who calls the shots?', Review of African Political Economy 32(104), 317-340.

Froelich, K.A., 1999, 'Diversification of revenue strategies: Evolving resource dependence in nonprofit organizations', Nonprofit and Voluntary Sector Quarterly 28(3), 246-268. https://doi.org/10.1177/0899764099283002

Gras, D. \& Mendoza-Abarca, K.I., 2014, 'Risky business? The survival implications of exploiting commercial opportunities by nonprofits', Journal of Business Venturing 29(3), 392-404. https://doi.org/10.1016/j.jbusvent.2013.05.003

Grasse, N.J., Whaley, K.M. \& Ihrke, D.M., 2015, 'Modern portfolio theory and nonprofit arts organizations: Identifying the efficient frontier', Nonprofit and Voluntary Sector Quarterly 45(4), 825-843. https://doi.org/10.1177/0899764015603204

Grimes, M., 2010, 'Strategic sensemaking within funding relationships: The effects of performance measurement on organizational identity in the social sector', Entrepreneurship Theory and Practice 34(4), 763-783. https://doi.org/10.1111/ j.1540-6520.2010.00398.x

Habib, A., 2005, 'State-civil society relations in post-apartheid South Africa', Social Research 72(3), 671-692.

Habib, A. \& Taylor, R., 1999, 'South Africa: Anti-apartheid NPOs in transition', Voluntas: International Journal of Voluntary and Nonprofit Organizations 10(1), 73-82. https://doi.org/10.1023/A:1021495821397

Hailey, J. \& Salway, M., 2016, 'New routes to CSO sustainability: The strategic shift to social enterprise and social investment', Development in Practice 26(5), 580-591. https://doi.org/10.1080/09614524.2016.1188886

Haltofová, P. \& Štěpánková, P., 2014, 'An application of the Boston Matrix within financial analysis of NPOs', Procedia - Social and Behavioral Sciences 147(83), 56-63. https://doi.org/10.1016/j.sbspro.2014.07.103

Hayman, R., 2016, 'Unpacking civil society sustainability: Looking back, broader, deeper, forward', Development in Practice 26(5), 670-680. https://doi.org/10.108 0/09614524.2016.1191439

Hershey, M., 2013, 'Explaining the non-governmental organization (NPO) boom: The case of HIV/AIDS NPOs in Kenya', Journal of Eastern African Studies 7(4), 671-690. https://doi.org/10.1080/17531055.2013.818776

Hillman, A.J.W., 2009, 'Resource dependence theory: A review', Journal of Management 35(6), 1404-1427. https://doi.org/10.1177/0149206309343469

Husy, D. \& Taback, R., 2005, Assessment of NPO Act, Department of Social Development, viewed 11 October 2019, from http://pmg-assets.s3-website-euwest-1.amazonaws.com/docs/100615NPOImpact\%20Assessment.pdf.

Ilhan, H., 2013, 'Non-profit organizations as providers of public goods', Yonetim ve Ekonomi 20(1), 95-104

Julie, F., 2010, 'The roots of the NPO crisis in South Africa: A look beyond the surface', International Journal of Civil Society Law 8(1), 9-28.

Kajiita, R.M. \& Kang'ethe, S., 2017, 'Appreciating the diversity of NPO's towards service delivery in South Africa: Drawing evidences from Eastern Cape Province', Insight on Africa 9(2), 126-140. https://doi.org/10.1177/0975087817707444 
Kerlin, J.A. \& Pollak, T.H., 2011, 'Nonprofit commercial revenue: A replacement for declining government grants and private contributions?', The American Review of Public Administration 41(6), 686-704. https://doi.org/10.1177/02750740 10387293

Lehner, O.M., 2013, 'Crowdfunding social ventures: A model and research agenda', Venture Capital 15(4), 289-311. https://doi.org/10.1080/13691066.2013. Venture
782624

Leonard, L., 2014, 'Characterising civil society and its challenges in post-apartheid South Africa', Social Dynamics 40(2), 371-391. https://doi.org/10.1080/02533952 .2014.936725

Liefferink, M. \& Van Eeden, E.S., 2010, 'Proactive environmental activism to promote the remediation of mined land and acid mine drainage: A success story from the South African goldfields', The Journal for Transdisciplinary Research in Southern Africa 5(1), 51-71.

Lowvelder, 2018, Lottery grants under investigation, viewed 03 April 2019, from https://lowvelder.co.za/459724/lottery-grants-investigation.

Lu, J., 2015, 'Which nonprofit gets more government funding? Nonprofits' organizationa attributes and their receipts of government funding', Nonprofit Management and Leadership 25(3), 297-312. https://doi.org/10.1002/nml.21124

Mayer, W.J., Wang, H., Egginton, J.F. \& Flint, H.S., 2014, 'The impact of revenue diversification on expected revenue and volatility for nonprofit organizations' Nonprofit and Voluntary Sector Quarterly 43(2), 374-392. https://doi.org/ 10.1177/0899764012464696

McKay, T.J.M., Mbanda, J.T. \& Lawton, M., 2015, 'Exploring the challenges facing solid waste sector in Douala, Cameroon', Environmental Economics 6(3), 93-102.

Morris, M.H., Webb, J.W. \& Franklin, R.J., 2011, 'Understanding the manifestation of entrepreneurial orientation in the nonprofit context', Entrepreneurship Theory and Practice 35(5), 947-971. https://doi.org/10.1111/j.1540-6520.2011. 00453.x

National Lotteries Commission, 2019, Impact of illegal lotteries to the national lottery in South Africa, viewed 13 September 2019, from http://www.nlcsa.org. za/wp-content/uploads/2019/01/Impact-of-Illegal-Lotteries-Research-ReportFINAL.pdf.

News24, 2012, NPOs demand audit of Lottery payments, viewed 03 April 2019, from https://www.news24.com/SouthAfrica/News/NPOs-demand-audit-of-Lotterypayments-20120118.

Patel, L., 2012, 'Developmental social policy, social welfare services and the non-profit sector in South Africa', Social Policy \& Administration 46(6), 603-618. https://doi. org/10.1111/j.1467-9515.2012.00858.x
Reith, S., 2010, 'Money, power, and donor-NPO partnerships', Development in Practice 20(3), 446-455. https://doi.org/10.1080/09614521003709932

Salamon, L.M., Sokolowski, S.W., Haddock, M.A. \& Rice, H.S., 2013, The state of global civil society and volunteering: Latest findings from the implementation of the UN nonprofit handbook, Center for Civil Society Studies Working Paper, 49 , viewed 11 October 2019, from http://ccss.jhu.edu/wp-content/plugins/download-monitor/ download.php?id=JHU_Global-Civil-Society-Volunteering_FINAL_3.2013.pdf.

SANGONet, 2018, South African NGO Movement Challenge, viewed 04 April 2019, from http://www.ngopulse.org/article/2018/03/15/south-african-ngo-movementchallenge.

Saunders, M. \& Lewis, P., 2012, Doing research in business and management, Pearson, Edinburgh Gate.

South African Government n.d., National Development Plan 2030, viewed 09 September 2019, from https://www.gov.za/issues/national-development-plan-2030.

Statistics South Africa (StatsSA), 2012, Statistics of the non-profit sector for South Africa, Pretoria, viewed 11 October 2019, from http://www.statssa.gov.za/ publications/D04072/D040722012.pdf.

Stecker, M.J., 2014, 'Revolutionizing the nonprofit sector through social entrepreneurship', Journal of Economic Issues 48(2), 349-358. https://doi.org/ 10.2753/JEI0021-3624480208

Suleiman, L., 2013, 'The NPOs and the grand illusions of development and democracy', Voluntas: International Journal of Voluntary and Nonprofit Organizations 24(1), 241-261. https://doi.org/10.1007/s11266-012-9337-2

Swilling, M. \& Russell, B., 2002, The size and scope of the non-profit sector in South Africa, Centre for Civil Society, University of Natal, HSRC, Pretoria

Unerman, J. \& O'Dwyer, B., 2010, 'NPO accountability and sustainability issues in the changing global environment', Public Management Review 12(4), 475-486. https://doi.org/10.1080/14719037.2010.496258

Van Pletzen, E., Zulliger, R., Moshabela, M. \& Schneider, H., 2014, 'The size, characteristics and partnership networks of the health-related non-profit sector in three regions of South Africa: Implications of changing primary health care policy for community-based care', Health Policy and Planning 29(6), 742-752. https://doi. org/10.1093/heapol/czt058

Warshawsky, D.N., 2016, 'Civil society and public-private partnerships: Case study of the Agri-FoodBank in South Africa', Social \& Cultural Geography 17(3), 423-443. https://doi.org/10.1080/14649365.2015.1077266

Yang, A.H., Lee, P.-Y. \& Chang, T.Y., 2011, 'Does self-financing matter? Recalibrating the rationale of NPOs' self-reliance in search of sustainability', Journal of Asian Public Policy 4(3), 263-278. https://doi.org/10.1080/17516234.2011.630218

Zikmund, W. G., Babin, B. J., Carr, J. C., \& Griffin, M. (2013). Business Research Methods. Cengage Learning, Mason, USA. 


\section{Appendix 1}

\section{Semi-structured interview guide}

1. What are the organisation's financial strengths and weaknesses?

2. Does the organisation have relevant and necessary capacity to be financially sustainable?

3. Who is responsible for ensuring that the organisation is financially sound and sustainable?

4. What accountability systems are in place to ensure financial sustainability?

5. Is the organisation aware of what it needs in order to be financially sustainable or to maintain its good financial status into the future?

6. How often does the organisation review and revise its funding and financial strategies?

7. How would the organisation react to a withdrawal of support from a major donor?

8. How does the organisation fund its programmes? Briefly describe the funding and revenue sources (historical, current, future)?

9. How does the organisation identify new opportunities for funding?

10. How does the organisation measure, review and evaluate performance of its funding sources against its own objectives and overall strategy?

11. What percentage of funds does the organisation receive from its main funding source (donor) of the organisation's total funds?

12. Which alternative revenue sources has the organisation identified in the past 3 years?

13. Is the organisation in a position to develop new funding and revenue sources?

14. What is the nature of the organisation's relationship with its donors? 